\title{
A history of railway fires in Ontario's forests
}

\author{
by Mary R. Grunstra ${ }^{1}$ and David L. Martell ${ }^{1, *}$
}

\begin{abstract}
Railways have played a pivotal role in the social and economic development of the province of Ontario but their construction and operation have contributed to the occurrence of forest fires that threaten public safety, property and forest resources. Over the past century, changes in policy and technology have substantially reduced the number of railway fires that occur in the province each year. We have created an historical timeline to describe trends in railway fire activity between 1914 and 2011 and we use graphs of railway fire occurrence, area burned and railway activity over time to explore relationships between the incidence of railway fires, railway activity, and changes in policy and technology that have impacted railway fire management.
\end{abstract}

Keywords: area burned, fire occurrence, fire prevention, human-caused forest fire, ignition source, railroad, wildland fire management

\section{RÉSUMÉ}

Les chemins de fer ont joué un rôle déterminant dans le développement social et économique de la province de l'Ontario, mais leur construction et leur utilisation ont provoqué des feux de forêt qui ont menacé la sécurité des habitants, leurs propriétés et les ressources forestières. Au cours du dernier siècle, les modifications apportées aux politiques et aux technologies ont permis de réduire substantiellement le nombre de feux provoqués par les chemins de fer qui surviennent dans la province chaque année. Nous avons élaboré une chronologie historique qui décrit les tendances observées parmi les activités ferroviaires de 1914 à 2010 et nous utilisons les graphiques sur loccurrence des feux de chemins de fer, les superficies ravagées et l'activité ferroviaire en fonction du temps pour explorer les relations entre l'incidence des feux de chemins de fer, lactivité ferroviaire et les modifications apportées aux politiques et aux technologies qui ont eu un effet sur la gestion des feux de chemins de fer.

Mots clés : superficie ravage, occurrence des feux, prévention des feux, feux de forêt dorigine humaine, source d'inflammation, chemin de fer, gestion des feux de forêt

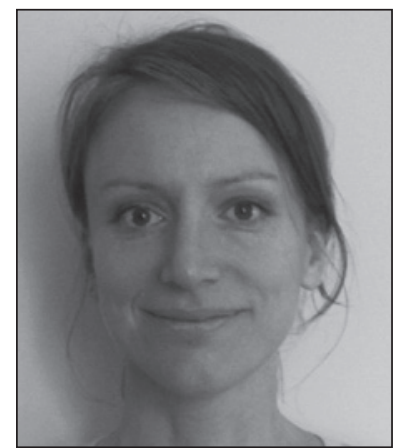

Mary R. Grunstra

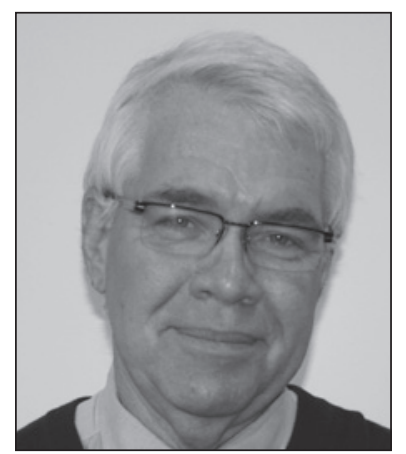

David L. Martell

\section{Introduction}

The first railway in Canada opened in 1836. Over the next hundred years railroad construction boomed and railways stretched across the province and into northern Ontario. Railways were lauded for the progress they brought in transportation, communication, and industry. By 1910 however, railways were also cited as "the most frequent cause of fire" in forest regions (Leavitt 1928). Since the early $20^{\text {th }}$ century, developments in railway technologies and the implementation of new legislation have effected a marked reduction in the annual number of railway fires. In this paper, we investigate trends in

the number and size of railway fires reported in Ontario since 1914 , as well as changes in railway policy and technology that have impacted railway fire management.

\section{Historical Perspective on Railway Forest Fire Protection}

In the early 1900s, railway fires were frequently ignited by chimney sparks from wood- and coal-burning locomotives, or by live coals dumped hot onto the railroads (ODLFM 1907). Railroad construction was also a significant source of railway fire, since construction crews used fire to clear land for laying the rights-of-way and exhibited no "effort to preserve the forest from destruction" (ODLFM 1909, Leavitt 1915). Railway fire ignition was compounded by slash buildup along the rights-of-way, left over from railroad construction and allowed to collect for years (ODLFM 1909). Though it was recognized early as a key factor in mitigating railway fire hazards, slash disposal along railroads was nevertheless unheard of in the early $20^{\text {th }}$ century (Leavitt 1915). A lack of effective legislation made it difficult for fire management agencies to limit the damage that resulted from railway construction and operation. Although the government of Ontario was responsible for forest fire management, provincial authorities were incapable of enforcing forest protection, since federal legislation regulated railway practices (ODLFM 1909).

\footnotetext{
${ }^{1}$ Faculty of Forestry, University of Toronto, 33 Willcocks St., Toronto, Ontario M5S 3B3.

* Author to whom correspondence should be sent. E-mail: david.martell@utoronto.ca
} 


\section{Analysis of Trends in Railway Fires}

By 1915, prior to the 1917 adoption of the provincial Forest Fires Prevention Act but following the 1913 institution of General Order 107 of the federal Railway Act, Clyde Leavitt, the Chief Fire Inspector for the Board of Railway Commissioners for Canada and Chief Forester of Canada's Commission of Conservation, published a detailed assessment of railway fires in Canada. Leavitt noted the introduction of legislation protecting forests from railway fires. The federal Board of Railway Commissioners had begun increasing foot patrols on railway rights-of-way. In 1907, the use of lignite coal was banned as a locomotive fuel. The use of protective fire appliances was mandated on all locomotives and employee training on fire prevention and control instituted (Leavitt 1928). Finally, under General Order 107 and based on the "best evidence" that "of locomotive sparks capable of setting fire, a large percentage... fall within a distance of fifty feet from the track," a new regulation assigned railways with full responsibility for all fires occurring within 300 feet of the track; a rule that has survived (sometimes contested) to the present day in the $21^{\text {st }}$ century (Leavitt 1915).

Over the past 85 years, The Forestry Chronicle has published several articles that address the topic of railway fires. In 1928 Leavitt wrote Railway Fire Protection in Canada, in which he praised the advances made in railway fire prevention during the previous decade (Leavitt 1928). Herbert Beall, a pioneer of forest fire research who played a leading role in the development of Canada's national fire protection standards, next published Wartime Influence on Forest Fires in Canada in 1946. Beall noted that despite the substantial reduction in the number of railway fires witnessed in the 1920s and 1930s, with wartime increases in shipping and industry the number of reported railway fires had more than doubled across Canada (Beall 1946). One decade later, in his Theme Address - Fire Highlights in the Development of Forest Fire Protection in Canada, Beall again praised reductions in railway fire numbers (Beall 1955).
Recent government reports, including Transport Canada's Review of the Railway Safety Act (2007) and the Canadian Interagency Forest Fire Centre's Wildland Fires Resulting From Railway Operations - A Public Safety Threat (CIFFC 2007), suggest that railway fires are still a problem. In this paper, we follow up on The Forestry Chronicle publications by Leavitt and Beall, and on preliminary findings published in Along a rickety road: one hundred years of railway fire in Ontario's forests (Grunstra and Martell 2013), by investigating trends in railway fires over the past one hundred years. We also investigate railway fire occurrence, area burned, railway activity and changes in policy and technology to explore changes in railway fire management that have taken place over the past century. A complete description of the data used for this study is included in the Appendix.

\section{Results and Discussion}

Consistent with the observations of railway fires across Canada published by Leavitt (1928) and Beall $(1946,1955)$, there was a significant decrease in the number of railway fires in Ontario between 1914 and 1939 (Fig. 1). From 1940 onwards the number of railway fires appears to follow a somewhat cyclic pattern until approximately 1980, at which point a decreasing trend is again apparent. A graph showing annual area burned over time (Fig. 2) demonstrates that the area burned by railways fires is highly variable from year to year and that there are no apparent trends over the study period. Of interest, however, is the fact that some of the largest areas burned by railway fires reported in Ontario have occurred in the last several decades, revealing that while the number of railway fires appears to have generally decreased over the past thirty years, the risks posed by railway fires in general have not necessarily diminished.

Several developments that occurred in Ontario may help explain the reduction of railway fires reported between 1914 and 1939. First, locomotive inspections were instituted in 1917. Between 1917 and 1934 two provincial officers inspected the

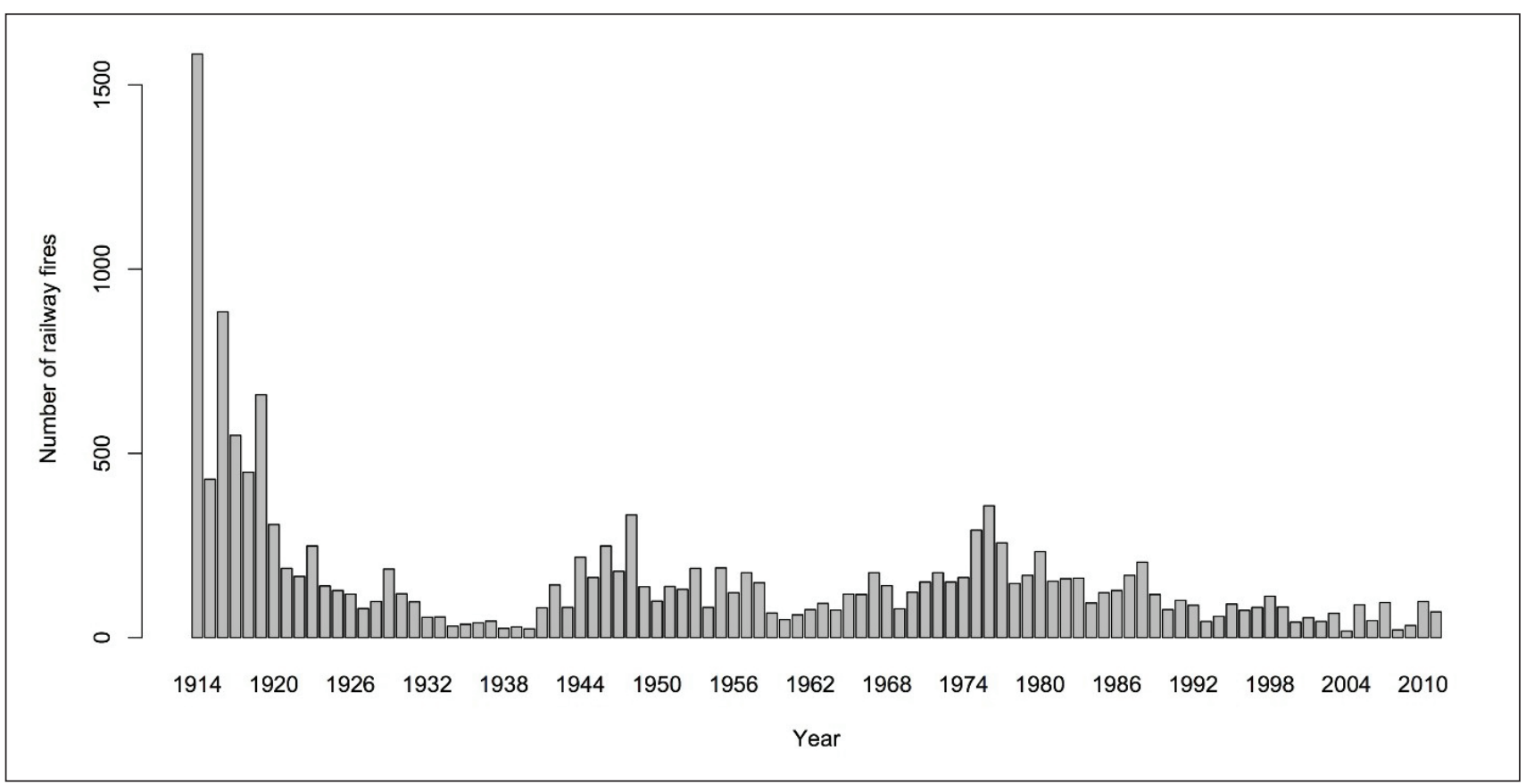

Fig. 1. The number of railway fires in Ontario, 1914-2011. 


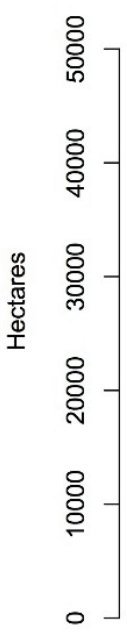

19141920

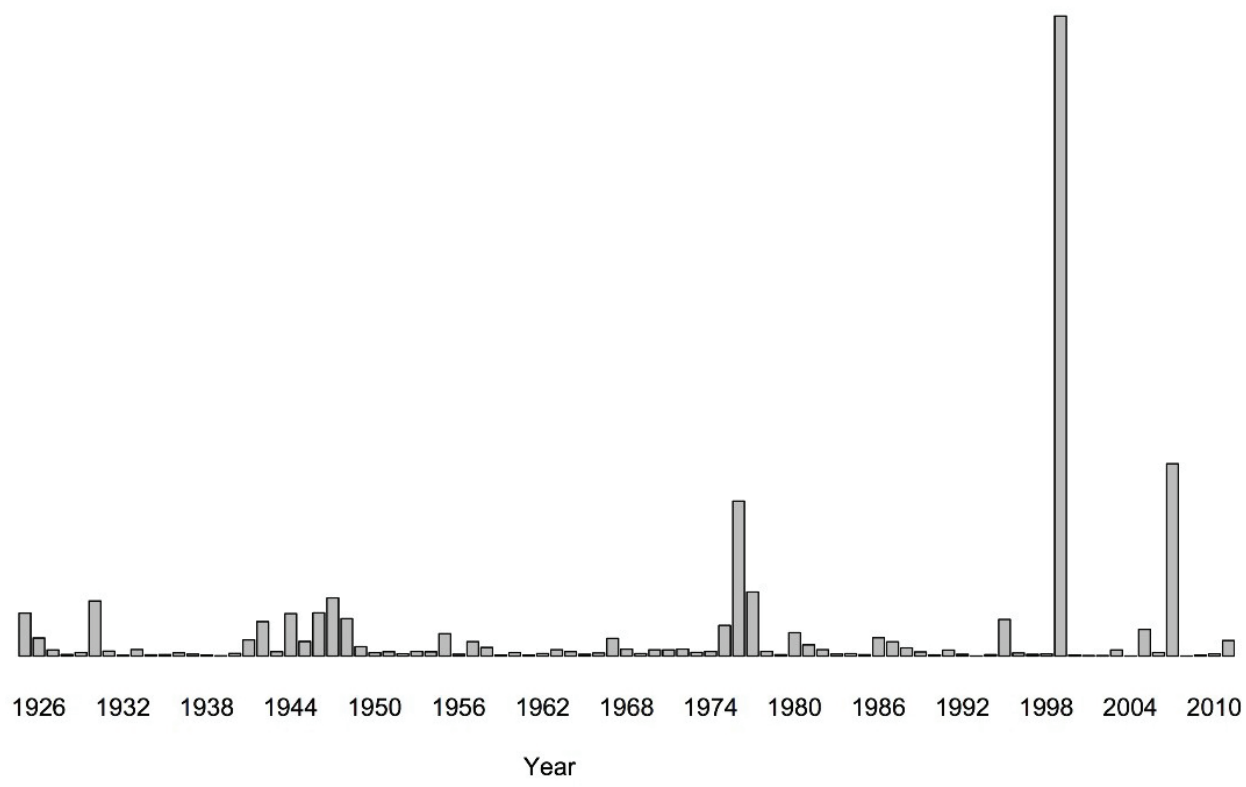

Fig. 2. Area burned by railway fires in Ontario, 1925-2011. No data are available on the area burned by railway fires prior to 1925.

fire prevention appliances on locomotives, reported on railroad conditions and on any fires starting within 300 feet of railroad (ODLFM 1917). Graphs of the percent of locomotive inspections that led to the discovery of defective fire prevention appliances and the reduction in railway fires from 1917 to 1934 (Fig. 3) show that the number of railway fires declined as the percent of inspections that revealed faulty equipment decreased, suggesting that a decrease in faulty fire prevention equipment may have helped reduce railway fires throughout the province.

Advances in fire detection also contributed to more effective railway fire management (Fig. 4). As early as 1904, Ontario posted a half-dozen foot patrols near railroad construction, each equipped with a shovel and canvas bucket (ODLFM 1904). Patrols were soon fortified by rail velocipedes and railway power speeders (ODLFM 1908). The rail velocipede was a hand-cranked vehicle that rode the railroad tracks and was capable of patrolling 20 miles of track per day. The power speeder, or railway motor car, was powered by a gasoline engine and could cover twice the ground of the rail velocipede, though was impracticable where railway traffic was high and dangerous where slopes too steep (Leavitt 1915). The velocipedes and power speeders enabled patrols, for the first time, to follow within 15 to 20 minutes of moving locomotives and extinguish railway fires while still small (ODLFM 1908).

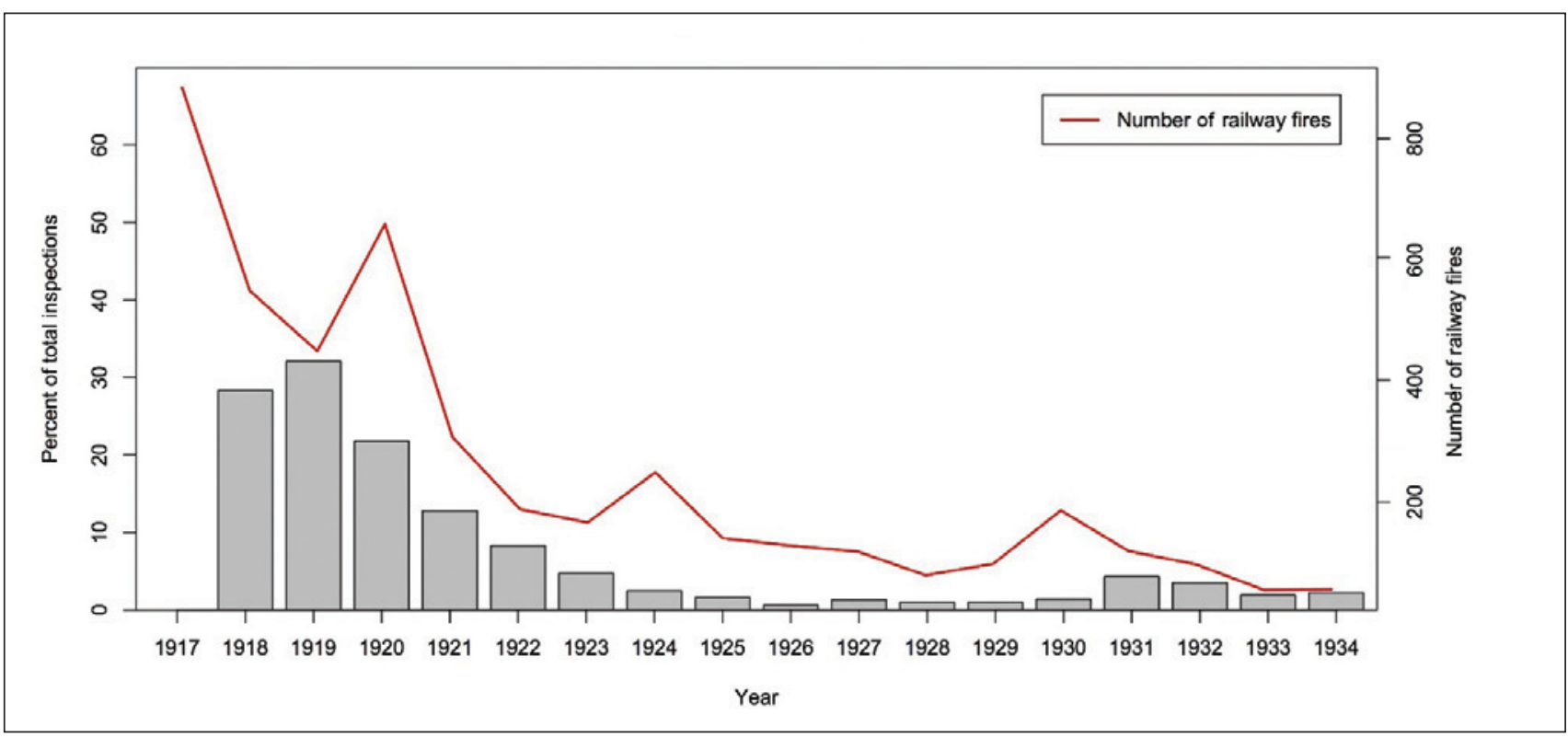

Fig. 3. The number of fires and corresponding percent of provincial locomotive inspections that revealed defective equipment in Ontario, 1918-1934. Inspections were ceased after 1934. 


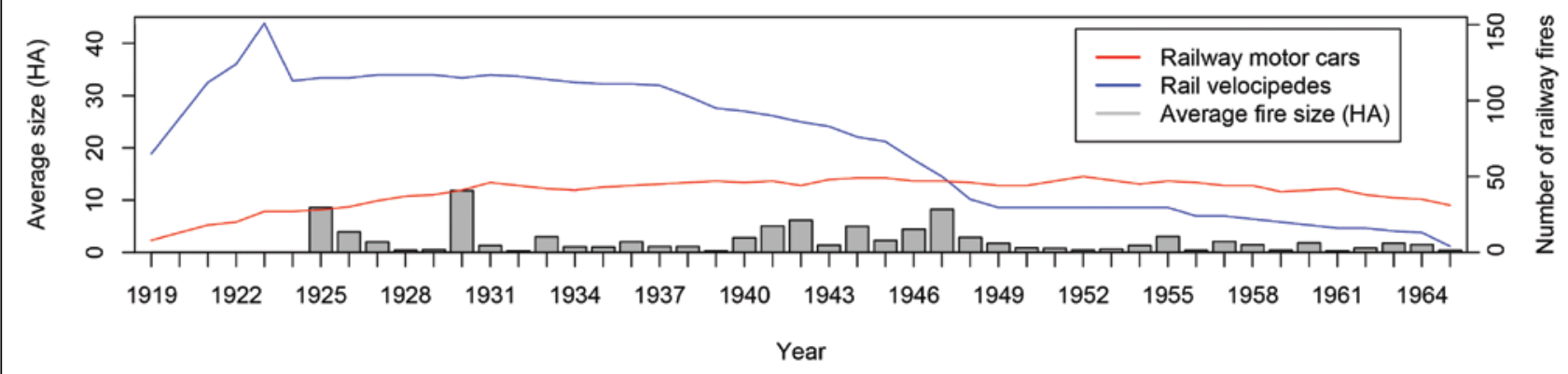

Fig. 4. The number of railway motor cars and railway velocipedes operating in Ontario between 1919 and 1965, the years for which data is available. The average fire size during this period is highly variable. No data could be found on either vehicle after 1966 , though both may have been used for several more years.

Other technological advances further enhanced the effectiveness of the railway patrols. In 1915, the manufacturing company Fairbanks-Morse and H.C. Johnson, a member of the Board of Railway Commissioners, developed the portable rotary pump, equipped with a four- to five-horsepower engine (Rajala 2005). Too heavy to transport on foot, by 1917, a number of patrol cars were equipped with pumps and 500 feet of hose (ODLF 1923, Rajala 2005). Such a large effect did these tools have on controlling railway fires that by the mid-1920s Ontario had spent over $\$ 100000$ obtaining more (Rajala 2005). While rail velocipedes, power speeders and portable water pumps could not prevent the occurrence of railway fires, they could be used to detect and suppress forest fires soon after ignition.

Research investigating the effectiveness of fuel management as a means of fire prevention was also developing at this time. Clifton D. Howe, dean of the Faculty of Forestry at the University of Toronto from 1919 to 1941, had begun exploring the benefits of burning slash left behind from timber harvests in British Columbia. His results indicated that prescribed burning reduced fuel load, thereby decreasing the risk of uncontrolled forest fires (Leavitt 1915). Fuel management along the right-of-ways also became the focus of early $20^{\text {th }}$ century railway regulation. General Order 107 implemented mandatory annual evaluations of railroad conditions, burning flammable matter and vegetation along the rights-of-way, and ploughing or digging along one or both sides of the track to reduce fuel load (ODLFM 1915). Still problematic, however, was the slash left behind by timber operations occurring very close to the rights-of-way. In 1915 the Minister of Lands and Forests noted that

"...within a few feet of the right-of-way timber op-

erators are allowed to create fire hazards which make

fire prevention almost impossible..." (ODLFM 1915).

Even after right-of-way clearing was provincially and federally mandated, "hang-over fires" were caused by debris burning that was used to clean up the rights-of-way in early spring. Referred to today by fire managers as holdover fires, which can be caused by both human agents and lightning, these undetected fires burned "deep into the dry ground..., breaking out again days after all indications of fire had disappeared on the surface," revealing yet another challenge to railway fire management (ODLF 1923).

Canada's transition from steam to diesel locomotives appears to have impacted railway fire activity (Fig. 5). Lignite coal, a highly combustible fuel infamous for starting forest fires, was banned in 1907 (Leavitt 1928). The use of charcoal as a locomotive fuel ceased completely in 1929, of anthracite coal in 1947, of wood in 1955, and of bituminous coal in 1965. Fuel oil was used into the 1950s, at which point diesel oil became the dominant locomotive fuel (Statistics Canada 1919-1995). While the shift from solid to liquid fuels likely decreased incidences of live sparks emitted through exhaust and hot embers left on the railroads, the transition, which occurred relatively quickly between 1946 and 1962, did not entirely eliminate railway fire starts. In a study modelling the effectiveness of spark arrestors and brake shoes on wildfire prevention between the 1950s and 1970s in the US, Pottharst and Mar (1981) note that other sources of ignition include railway maintenance, particularly cutting, welding and grinding the track; flares or fusees; smoking employees and passengers; and miscellaneous activities.

Consistent with the observations of Pottharst and Mar (1981), the most common sources of ignition of approximately 6000 railway fires reported in Ontario between 1960 and 2010 (Fig. 6 and Fig. 7) include the application of brake shoes on tracks (40.7\%), sparks emitted in locomotive exhaust (21.4\%), burning along the rights-of-way (5.25\%), railway grinding and cutting to remove irregularities from the surface of the track (4.8\%), smoking materials belonging to passengers and staff $(4.5 \%)$, ignition from fusees or flares (3.5\%), railway tie burning (3.7\%), operating mechanical equipment $(2.6 \%)$, miscellaneous causes $(2.5 \%)$, and overheated journal boxes, involving the metal box containing the train car bearings (1.2\%). Another $6.1 \%$ of railway fires during this period were attributed to unknown ignition sources (OMNR 2012).

The decrease in railway fires attributed to brake shoes may have been influenced by the development, in the 1980s, of low-sparking, high-phosphorous cast-metal brake shoes (Pottharst and Mar 1981). The dynamic braking system, wherein mechanical energy from the wheels of the train is converted into electric and heat energy, was also developed for railway transport around this time and proved a viable substitute to conventional braking systems, further reducing sparks caused by braking (Pottharst and Mar 1981). Today in Canada, all new locomotives are built in accordance with the Association of American Railroads' Manual of Standards and Recommended Practices. Railway 


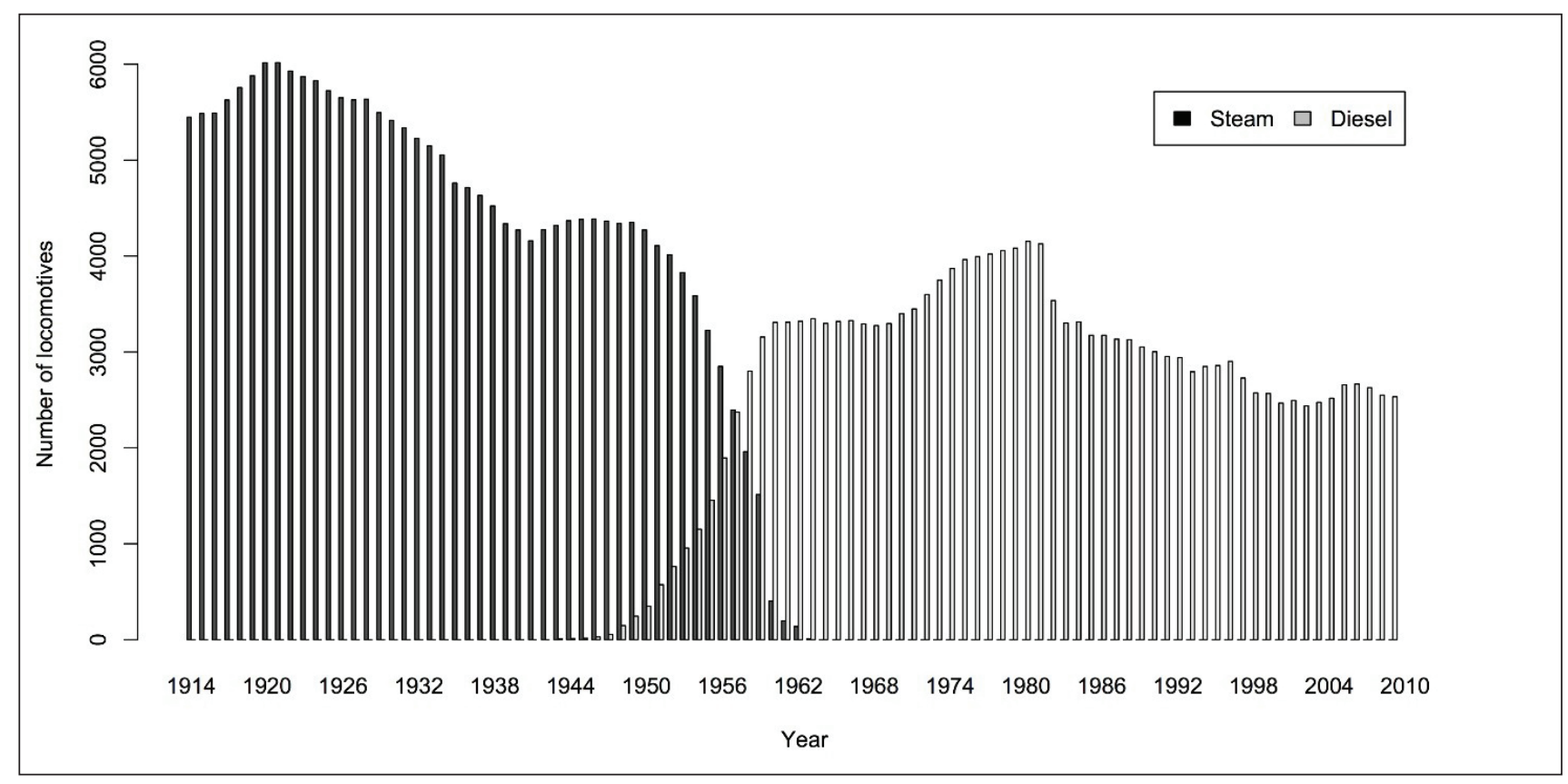

Fig. 5. Changes in locomotive technology can be seen in the numbers of steam and diesel locomotives used across Canada between 1914 and 2009 .

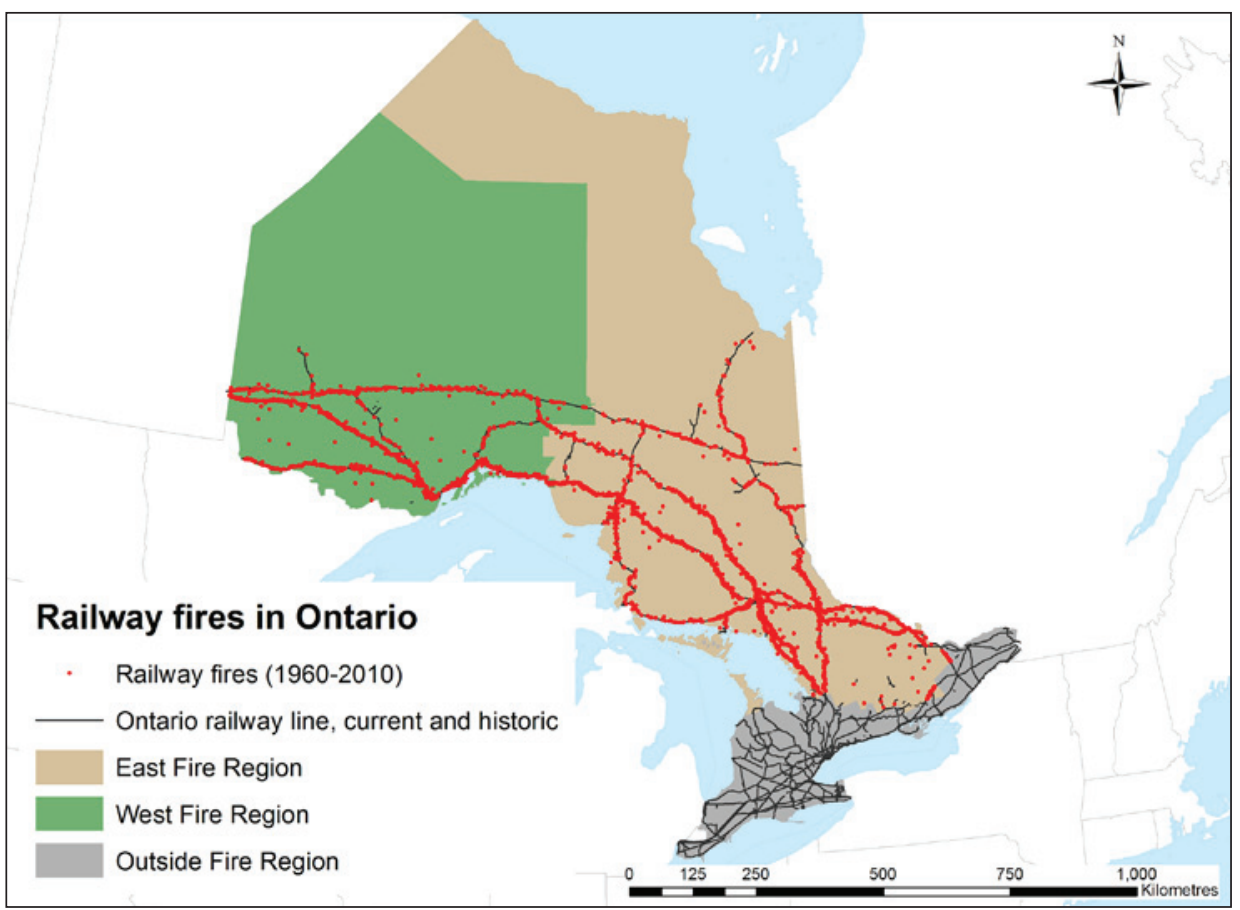

Fig. 6. Railway fires in Ontario from 1960 to 2010 . Railway rights-of-way are shown in black and railway fires in red. Some railway fires were reported to have occurred some distance from a railway. We assumed (see the Appendix) the locations of those railway fires were recorded incorrectly but plotted them in the locations recorded in the digital fire archive.

companies are also required to invest in prevention equipment, including spark arresters on exhaust stacks, and are prohibited from using any locomotive in which the journal bearings show signs of overheating (Transport Canada 2007, 2010). As of 2010, all new freight trains, excluding yard locomotives, must also be equipped with dynamic brakes (Transport Canada 2010).

\section{Conclusions}

Substantial reductions in the number of railway fires have been realized over the past century, simultaneous with changes in policy and technology that have undoubtedly affected railway fire activity (Fig. 8). In particular, with the institution of the federal Railway Act and the creation of the Board of Railway Commissioners in 1903, of General Order No. 107 in 1913, and of Ontario's Forest Fires Prevention Act of 1917, legislation was implemented to protect forests from railway fires. That legislation called for the establishment of mandatory fire-prevention appliances on all locomotives, enforcement of new regulations, a system of railway inspections, and assigned legal responsibility for fires occurring within 300 feet of the rights-of-way to railway companies. Early railway fire detection, made possible by the adoption of the railway velocipede and railway motor car, also enhanced firefighters' abilities to suppress railway fires while they were small. Changing technology, particularly the transition from steam to diesel-electric locomotives, likely impacted the number of firebrands deposited on rights-of-way. The subsequent development of low-sparking brake shoes and braking systems have, more recently, also helped decrease the risk of railway fires. 


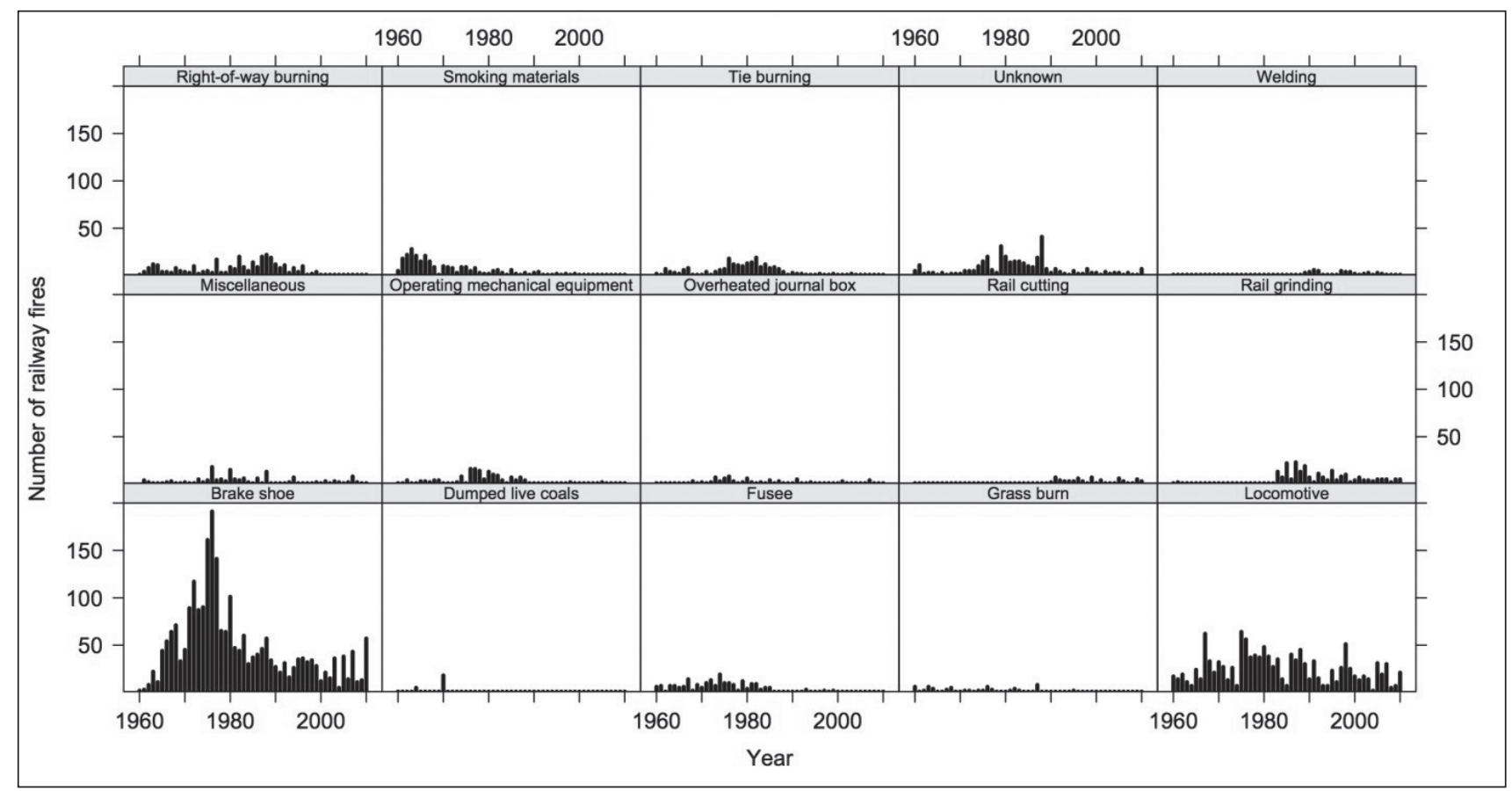

Fig. 7. Sources of ignition of railway fires in Ontario, by specific cause.

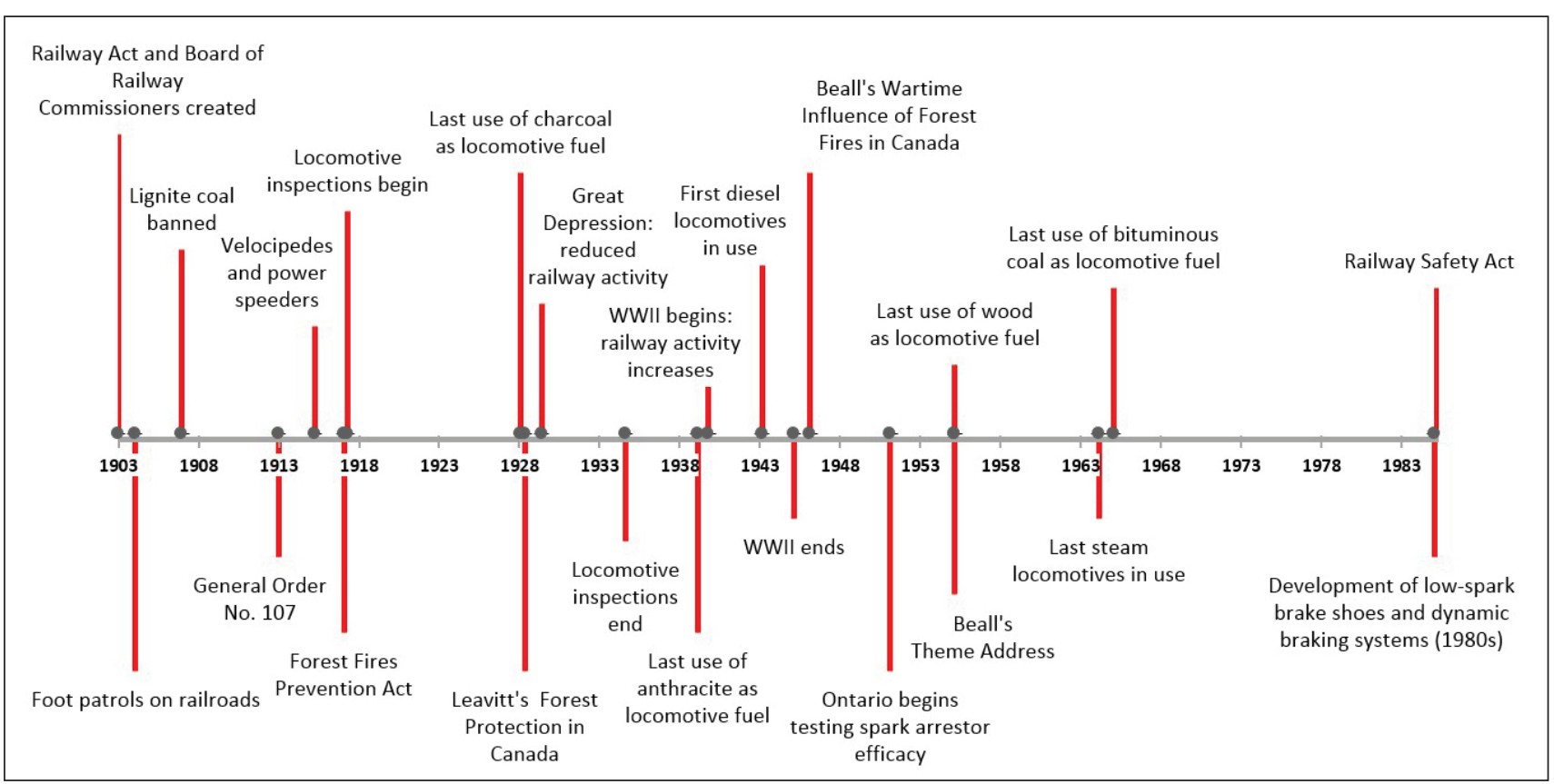

Fig. 8. A timeline of significant changes to policy, technology and railway activity made over the past one hundred years in Canada. This diagram was produced using a template (TC102930035 Excel Timeline Template) downloaded from http://office.microsoft.com/enca/templates/project-timeline-TC102930035.aspx [Accessed 12 November, 2013].

As noted by both Leavitt (1928) and Beall $(1946,1955)$ in their observations about railway fires across Canada, railway fires in Ontario have decreased substantially in number since the early years of the $20^{\text {th }}$ century. While the number of railway fires in Ontario have fluctuated throughout the century, a decreasing trend has been seen in railway fire activity since approximately 1980. Over the past 20 years an average of approximately 65 fires have occurred every year, a considerable decrease when compared to the 20-year average from 1914 to 1933, wherein on average 250 fires occurred annually. Nevertheless, the area burned by railway fires every year remains highly variable and some of the largest reported annual areas burned by railway fires have occurred in recent decades. Despite the developments that appear to have contributed to reductions in the number of railway fires, the area burned by railway fires is a reminder that they still present a significant threat to public safety, property and forest resources. Further research, particularly focusing on the spatial distribution of railway fires throughout the province, may shed light on forest regions and sections of railway track that are most vulnerable to ignition from railway operations. 


\section{Acknowledgements}

This research was supported by a National Sciences and Engineering Research Council of Canada Discovery grant to David Martell. The Ontario Ministry of Natural Resources provided us with their fire data. We thank Bill Droog of the Ontario Ministry of Natural Resources who shared some of his extensive knowledge of railway fires with us. We also thank the special issue guest editor, the Associate Editor and three anonymous reviewers for their helpful comments on earlier versions of this manuscript.

\section{References}

Beall, H.W. 1946. Wartime Influence on Forest Fires in Canada. For. Chron. 22(1): 25-29. doi:10.5558/tfc22025-1.

Beall, H.W. 1955. Theme Address- Fire Highlights in the Development of Forest Fire Protection in Canada. For. Chron. 31(4): 332-337. doi: $10.5558 / \mathrm{tfc} 31332-4$.

DMTI Spatial. 2012. CanMap RouteLogistics. [Geospatial data]. Markham, ON.

Grunstra, M. and D. L. Martell. 2013. Along a rickety road: one hundred years of railway fire in Ontario's forests. Forestory 4(1): 5-10.

Leavitt, C. 1915. Forest Protection in Canada: 1912-1914. William Briggs, Toronto, ON.

Leavitt, C. 1928. Railway Fire Protection in Canada. For. Chron. 4(4): 10-19. doi: 10.5558/tfc4010-4.

[ODLFM ] Ontario Department of Lands, Forests and Mines. 1904-1919. Report of the Minister of Lands, Forests and Mines of the Province of Ontario. King's Printer, Toronto, ON.

[ODLF] Ontario Department of Lands and Forests. 1920-1968. Report of the Minister of Lands and Forests of the Province of Ontario. Clarkson W. James, Toronto, ON.

[OMNR] Ontario Ministry of Natural Resources. 1992. Fire Information Report and Fire Cost Report Instruction Manual. .2012. Digital Fire Archive.

Pottharst, E. and B.W. Mar. 1981. Wildfire prevention engineering systems. Can. J. For. Res. 11: 324-333. doi: 10.1139/x81-044.

[CIFFC] Railway Fire Prevention Task Team, Canadian Interagency Forest Fire Centre. 2007. Wildland Fires Resulting From Railway Operations - A Public Safety Threat. Submission to the Advisory Panel, Railway Safety Act Review [online]. Available at http://www. tc.gc.ca/media/documents/rsa-lsf/ciffc.pdf [Accessed 30 October, 2013].

Rajala, R. 2005. Fed, Forests, and Fire: A Century of Canadian Forestry Innovation. Canada Science and Technology Museum, Ottawa.

Statistics Canada. 1919-1995. Railway Transport: Comparative Statistics. Ottawa.

Statistics Canada. 2008. Historical Statistics tables T5_18, T28_38 [Data files]. Available from http://www.statcan.gc.ca/pub/11-516-x/\#R [Accessed 30 October, 2013].

Statistics Canada. 2013. CANSIM tables 404-0014, 404-0015, \& 4040017 [Data files]. Available from http://www5.statcan.gc.ca/cansim/a3 3?lang=eng\&spMode $=$ tables $\&$ themeID $=4011 \&$ stByVal $=2 \& R T=T A B$ LE [Accessed 30 October, 2013].

Transport Canada. 2007. Stronger Ties: A Shared Commitment to Railway Safety. Review of the Railway Safety Act. Report of the Advisory Panel. Available at http://www.tc.gc.ca/media/documents/railsafety/ TRANSPORT_Stronger_Ties_Report_FINAL_e.pdf [Accessed 30 October, 2013].

Transport Canada. 2010. Railway Locomotive Inspection and Safety Rules. TC O 0-122. Revised February $4^{\text {th }}, 2010$. Available at http:// www.tc.gc.ca/media/documents/railsafety/tc0_112e.pdf [Accessed 30 October, 2013].

Urquhart, M. C., and K. A. H. Buckley. 1965. Historical statistics of Canada. Cambridge University Press, Cambridge, UK.

Woodard, P. M. and W. Renke. 1999. Assigning liability to railways without evidence. For. Chron. 75(2): 257-259. Doi: 10.5558/tfc75257-2.

\section{Appendix}

Aggregate data concerning the number of railway fires and human caused fires reported in Ontario from 1914 to 1959, railway inspections from 1917 to 1940, and railway velocipedes and motor cars from 1919 to 1968 were obtained from the Annual Reports of the Minister of Lands, Forests, and Mines of Ontario from the years 1914 to 1919, and from the Annual Reports of the Minister of Lands and Forests of Ontario for the years 1920 to 1968. Spatial data that describe the number, locations, and specific causes of railway fires were obtained from the Ontario Ministry of Natural Resource's digital fire archive for the years 1960 to 2010. Because the Annual Reports do not report the actual number of railway fires for the year 1916, but railways caused just under $50 \%$ of the total number of forest fires that year, we assumed that railway fires were responsible for $49 \%$ of all 1916 forest fires; a figure from which we tabulated the number of railway fires for the year. Where data describing the number of velocipedes and railway motor cars were missing, the average was calculated from the year prior to and following the missing observation, and used for that year.

We used national railway statistics as surrogate measures of railway activity in the province of Ontario as such data were not consistently available at the provincial level. Data concerning locomotives, and locomotive fuel consumption were obtained from Historical Statistics of Canada (Urquhart and Buckley 1965) from 1914 to 1960 and from Statistics Canada's Railway Transport series, which covers the years 1919 to 1995. Data were also obtained from Statistics Canada Historical Statistics tables from 1946 to 1975 (Statistics Canada 2008) and Statistics Canada’s CanSim tables from 1986 to 2009 (Statistics Canada 2013). For the years 1948 and 1951, no data on fuels were available so we calculated the average from the years prior to and following the missing observation, and used the average for these two years. Geospatial data on railroads were obtained from DMTI Spatial's 2012 CanMap Route Logistics, and on the Ontario fire regions from the Ontario Ministry of Natural Resources.

There is some debate over what constitutes a railway fire (Woodard and Renke 1999). The OMNR defines railway fires as "all fires caused by persons or equipment associated with any phase of railway operation," and uses "the most probable cause of the fire and the group responsible for causing the fire" (OMNR 1992). Fires occurring on the rights-of-way, the ignition of which were attributed to causes other than the railway operation (i.e., fires caused by lightning) are not classified as railway fires (OMNR 1992). While we acknowledge that some debate exists over the precision of railway fire data, for this analysis we assume that any fire classified as a railway fire by the OMNR and its predecessors was a railway fire.

The railway fires reported in Ontario between 1960 and 2010 are all located in the province's East or West Fire Regions. Forest fires occurring in southern Ontario, or the Outside Fire Region, were located outside of these two fire regions and are therefore not classified as forest fires nor included in the OMNR's digital fire archive. Of the approximately 6000 railway fires that were reported in Ontarios East and West Fire Regions between 1960 and 2010, just under $10 \%$ were located more than $2.75 \mathrm{~km}$ from current or historic railroad tracks. We assumed that the locations of these fires were incorrectly recorded. 